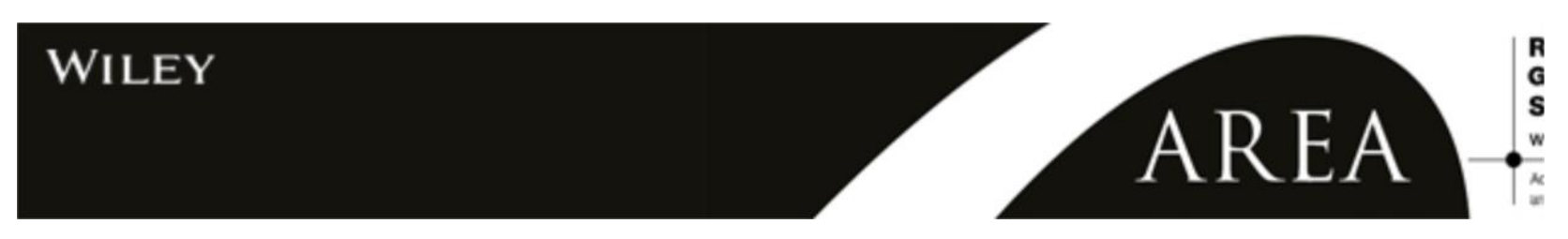

The geography of Australia's Marriage Law Postal Survey
outcome

\begin{tabular}{|c|c|}
\hline Journal: & Area \\
\hline Manuscript ID & Draft \\
\hline Manuscript Type: & Regular Paper \\
\hline Keywords: & $\begin{array}{l}\text { Same-sex marriage, Australia, regression, geographically-weighted } \\
\text { regression, LGBT, Australian Marriage Law Postal Survey }\end{array}$ \\
\hline Abstract: & $\begin{array}{l}\text { After years of public debate about same-sex marriage, the Australian } \\
\text { Government put the issue to the electorate in the 'Australian Marriage } \\
\text { Law Postal Survey' in late } 2017 \text {. The survey asked voters whether the } \\
\text { law should be changed to allow same-sex couples to marry. Nationally, } \\
61.6 \% \text { of voters responded 'Yes'. But there were marked variations by } \\
\text { electoral division, with the proportion of 'Yes' votes varying from } 26.1 \% \\
\text { to } 83.7 \% \text {. The aim of this paper is to explore the geographical pattern of } \\
\text { the percentage of voters responding 'Yes' by federal electoral division } \\
\text { and identify its correlates. Results of the survey by federal electoral } \\
\text { division were obtained from the Australian Bureau of Statistics (ABS); } \\
\text { other variables for electoral divisions were obtained from the ABS and } \\
\text { the Australian Electoral Commission. Multiple linear regression and } \\
\text { geographically weighted regression were employed to establish the } \\
\text { relationship between the percentage of 'Yes' responses at the electoral- } \\
\text { division level and the characteristics of electoral divisions' populations. In } \\
133 \text { of } 150 \text { electoral divisions there was a majority of 'Yes' responses. } \\
\text { Strong predictor variables of the percentage 'Yes' vote included the } \\
\text { proportions of: the population describing themselves as having no } \\
\text { religion, those with post-school educational qualifications, those with a } \\
\text { birthplace in Oceania, Europe or the Americas, and those who did not } \\
\text { vote for conservative parties in the } 2016 \text { federal election. A marginally } \\
\text { better fit was obtained with geographically-weighted regression. In } \\
\text { conclusion, the geographical pattern of responses in the Australian } \\
\text { Marriage Law Postal Survey is closely associated with a small number of } \\
\text { characteristics of an electoral division's population. }\end{array}$ \\
\hline
\end{tabular}





\title{
The geography of Australia's Marriage Law Postal Survey outcome
}

\begin{abstract}
After years of public debate about same-sex marriage, the Australian Government put the issue to the electorate in the 'Australian Marriage Law Postal Survey' in late 2017. The survey asked voters whether the law should be changed to allow same-sex couples to marry. Nationally, $61.6 \%$ of voters responded 'Yes'. But there were marked variations by electoral division, with the proportion of 'Yes' votes varying from $26.1 \%$ to $83.7 \%$. The aim of this paper is to explore the geographical pattern of the percentage of voters responding 'Yes' by federal electoral division and identify its correlates. Results of the survey by federal electoral division were obtained from the Australian Bureau of Statistics (ABS); other variables for electoral divisions were obtained from the ABS and the Australian Electoral Commission. Multiple linear regression and geographically weighted regression were employed to establish the relationship between the percentage of 'Yes' responses at the electoral-division level and the characteristics of electoral divisions' populations. In 133 of 150 electoral divisions there was a majority of 'Yes' responses. Strong predictor variables of the percentage 'Yes' vote included the proportions of: the population describing themselves as having no religion, those with post-school educational qualifications, those with a birthplace in Oceania, Europe or the Americas, and those who did not vote for conservative parties in the 2016 federal election. A marginally better fit was obtained with geographically-weighted regression. In conclusion, the geographical pattern of responses in the Australian Marriage Law Postal Survey is closely associated with a small number of characteristics of an electoral division's population.
\end{abstract}




\section{Keywords}

Same-sex marriage; Australia; Marriage Law Postal Survey; regression; geographicallyweighted regression; LGBT

\section{INTRODUCTION}

Marriage equality has been on the Australian political agenda for much of the present century, particularly after a number of countries introduced civil partnerships in the late 20th century and then same-sex marriage in the early 2000s (Chamie \& Mirkin, 2011). In 2004 the then Liberal-National Coalition Government amended the Marriage Act to explicitly restrict marriage in Australia to opposite-sex couples only and to prevent overseas same-sex marriages from being recognised in Australia (McKeown, 2017). Several attempts in subsequent years to introduce legislation in the federal parliament to allow for marriage irrespective of the partners' gender proved unsuccessful. However, Australian public opinion on the rights of same-sex couples and marriage equality shifted rapidly over the course of this century to become much more favourable (e.g. Perales \& Campbell, 2018; Smith, 2016), mirroring trends in other western countries such as the US (e.g. Armenia \& Troia, 2017; Baunach, 2012).

In the context of changing public opinion and divided views amongst its membership, the Liberal-National Coalition Government went to the 2016 election with a pledge to let the Australian people decide on amending the marriage law. The Coalition won the election and in August 2017 directed the Australian Bureau of Statistics (ABS) to canvass the views of the public. Effectively a plebiscite, the Australian Marriage Law Postal Survey (AMLPS) as it was officially called, was open to all those on the electoral register at 24th August 2017 -all Australian citizens aged 18 and over except those serving prison sentences of more than three 
years. Unusually, the whole exercise was conducted by post with voting open between 12th September and 7th November 2017. Participation was voluntary. Voters were asked "Should the law be changed to allow same-sex couples to marry?" and instructed to mark either a 'Yes' or 'No' box and then post back their completed form (ABS 2017a). The results announced by the ABS on 15th November 2017 revealed a participation rate of $79.5 \%$ of voters and a 'Yes' vote of $61.6 \%$ (excluding a small number of illegible forms). A bill to change the law was passed by parliament shortly afterwards, and the amended Marriage Act came into effect on the 9th December 2017. It represented a highly significant day not only for Australia's non-heterosexual population (Wilson \& Shalley, 2018), but also Australians more generally. According to the recent Life in Australia survey conducted by the Social Research Centre at the Australian National University, marriage equality was selected as the most significant event to have occurred in participants' lifetimes (Pennay et al., 2018).

The plebiscite results prompt questions such as 'Who voted 'Yes'?', 'Which areas voted 'Yes' to the greatest extent?' and 'What are the determinants of these patterns?'. Previous research on the correlates and determinants of support for marriage equality, and rights for same-sex couples more generally, emphasises religiosity, political views, education, age, gender, cultural background, and area of residence (e.g. Anderson et al., 2017; Oppenheimer et al., 2014; Sloane et al., 2017; Webb \& Chonody, 2014). A recent study by Perales \& Campbell (2018) used data from the Household, Income and Labour Dynamics in Australia (HILDA) Survey, the largest representative household panel survey in Australia consisting of about 20,000 individuals. Participants were asked to state the extent to which they agreed with the statement "Homosexual couples should have the same rights as heterosexual couples do". The authors found that strong support for the statement was obtained from individuals 
who were non-religious, highly educated, under 40 years of age, female, living in a

metropolitan area, high income, Australian-born and English-speaking, and non-heterosexual.

As part of the Marriage Law Postal Survey results, the ABS published the number and percentage of 'Yes' and 'No' votes for each of the 150 federal electoral divisions as well as voting participation rates by gender and broad age group (ABS 2017b). McAllister \& Snagovsky (2018) used these data to conduct an ecological analysis of the results, focusing primarily on the voting patterns of four socio-economic area types identified by factor analysis, and the views of local Members of Parliament (MPs) on same-sex marriage. They found that the percentage 'Yes' vote by electoral division was positively associated with affluence (defined as high levels of income, education, and occupation), the proportion of female (but not male) same-sex couples, plebiscite turnout, and the MPs' level of support for same-sex marriage; and negatively associated with immigrant areas (non-English speakers, newly arrived migrants and non-Christian religions) and more traditional electorates (with higher proportions of older married residents). Their linear regression model achieved an adjusted $\mathrm{R}^{2}$ of 0.78 . Other research has analysed the AMLPS results for different purposes. For example, Perales \& Todd (2018) found poorer health and wellbeing outcomes for lesbian, gay and bisexual individuals living in areas with higher percentage 'No' vote.

However, while many authors have examined the factors behind individual or area-level support for marriage equality or the rights of same-sex couples generally, little specific analysis of the geography of Australia's Marriage Law Postal Survey has been conducted to date. The aims of this paper are therefore to address the questions (1) What was the spatial pattern of the Australian Marriage Law Postal Survey outcome by electoral division? and(2) What are the correlates of the percentage 'Yes' vote? All ABS data from the plebiscite are 
aggregate counts by electoral division, rather than individual-level data, so we are unable to undertake individual-level analysis. However, we are able to examine spatial patterns of the outcome and their relationship to other variables, particularly given the relatively close timing of the latest census in August 2016 and the vote during September and October 2017. Our approach differs from that of McAllister \& Snagovsky (2018) in that we take an explicitly geographical perspective and use a small number of independent variables, mostly from the 2016 Census, rather than factor analysis. We used the micro-level findings of other studies, particularly Perales \& Campbell (2018), to inform the initial selection of independent variables. In addition to multiple linear regression we also applied geographically weighted regression to allow the independent variables to vary spatially in their influence.

\section{DATA AND METHODS}

\subsection{Data}

The dependent variable in our modelling was the percentage of 'Yes' responses to the question "Should the law be changed to allow same-sex couples to marry?". These data by federal electoral division were obtained from the results of the AMLPS published by the ABS in mid-November 2017 (ABS, 2017b). Australia is divided into 150 electoral divisions for elections to the House of Representatives, with the median Estimated Resident Population in 2016 being 160,600. While population sizes do not differ greatly, electoral divisions vary hugely in geographical extent, ranging from $32 \mathrm{~km}^{2}$ (Grayndler, inner Sydney) to 1.63 million $\mathrm{km}^{2}$ (Durack, outback Western Australia).

Based on the findings of previous research, an initial set of 11 independent variables was constructed from the AMLPS results (ABS, 2017b), the ABS 2016 Census of Population and Housing (ABS, 2017c), ABS Estimated Resident Populations (ABS, 2018), and results from 
the 2016 federal election published by the Australian Electoral Commission (AEC, 2017).

The variables are listed in Table 1 along with summary descriptive statistics. The full dataset is available in a supplementary file to this paper.

Table 1 about here

The participation rate, defined as the number of participants as a percentage of eligible voters, was obtained from the published AMLPS results. The participation of those aged 18-34 was included as a separate variable because younger voters tend to be more progressive than older voters (Armenia \& Troia, 2017). We expected higher participation of this age group in the survey to be positively correlated with a 'Yes' outcome.

All variables derived from 2016 Census data were created from data obtained via the ABS TableBuilder Pro tool (ABS, 2017c) and were restricted to Australian citizens aged 18 years and over as the eligible participating population. All were expected to be positively correlated with a 'Yes' outcome. The percentage of people identifying their religion as 'no religion' was used as a general indication of lack of religiosity and therefore less support for traditional sexual and moral attitudes (Perales et al., 2018). The percentage of non-Indigenous people born in Oceania (including Australia), Europe and the Americas was also used as a proxy for more open attitudes to sexual diversity due to greater acceptance of non-heterosexual orientations in many countries in those continents. The percentage of people with any postschool education was used as an indicator of openness to diversity in general, while the percentage of adults in a cohabiting same-sex relationship was expected to be indicative of relatively more supportive attitudes to sexual diversity in the local area. Theories of intergroup contact pose that interaction with individuals from stigmatised populations fosters 
understanding, personification and acceptance (e.g. Smith et al., 2009). The percentage of females and the percentage of younger people (aged 18-34) were included because we expected them to be generally more supportive of non-heterosexual partnerships. The percentage of people with personal incomes of $\$ 2,000$ or more per week was also expected to be positively correlated with a 'Yes' outcome.

Population density was calculated as the 2016 Estimated Resident Population (ERP) for each electoral division divided by the size of the electoral division in $\mathrm{km}^{2}$ (ABS 2018). We expected higher population density to be positively correlated with a 'Yes' outcome because individuals in densely population areas are more likely to interact with a greater diversity of people.

We also included the percentage of Coalition (Liberal and National party) votes from the 2016 federal election for the House of Representatives (AEC, 2017). Because of the preferential voting system in Australia these data consist of the two-party preferred vote between the Coalition and the other major party in the electorate (usually the Australian Labor Party). The Liberal/National Coalition includes both major conservative parties in Australian politics and we expected higher proportions of Coalition support to be negatively correlated with a 'Yes' vote.

\subsection{Methods}

To answer the first question 'What was the spatial distribution of the Australian Marriage Law Postal Survey outcome by electoral division?' choropleth maps of the percentage 'Yes' and 'No' votes were created in ArcGIS. These electoral divisions are shown in Figure 1; those referred to later in the paper are highlighted. 
Figure 1 about here

We then examined the bivariate relationships between the percentage 'Yes' vote and the 11 independent variables. The natural log was selected for three variables to obtain a more linear relationship with the 'Yes' percentage, these being: population density, percentage with a birthplace in Oceania, Europe or the Americas, and the percentage of individuals in cohabiting same-sex relationships. To analyse the correlates of the percentage 'Yes' vote we initially fitted an Ordinary Least Squares linear regression model in R (R Core Team, 2018) using all 11 independent variables (Model 1). A second model was then created using backwards step-wise regression to choose an optimised model without compromising model accuracy (Model 2). This was achieved with the R function "leapBackward" where 10-fold cross validation was used to estimate the average prediction error of the models (Kassambara, 2018). The function defined the best model as the one with the lowest Root Mean Squared Error (RMSE). The R code is available in the supplementary material.

We then applied geographically-weighted regression (GWR) to determine whether there was any spatial variability between the independent variables and the percentage of 'Yes' responses. A GWR model allows the coefficients of the independent variables to vary spatially and provides the opportunity to test whether this improves our understanding of how the independent variables impact the dependent variable in both strength and direction over space (Fotheringham et al., 2000). GWR4 software was used (Nakaya et al., 2016). Because of the geography of Australia, adaptive bi-square spatial kernels were used. These accommodate both the variation in population size of electoral divisions and the fact that geographically larger and sparsely populated electorates are located next to one another, as 
are smaller and more densely populated electorates (Fotheringham et al., 2002). GWR can incorporate coefficients that vary geographically as well as global coefficients which do not. We set population density as global and allowed all others to vary locally. The GWR4 program then selected the best model on the basis of the Akaike Information Criterion (AIC).

\section{RESULTS}

\subsection{Geography of the vote}

Nationally $61.6 \%$ of Australians who participated in the ALMPS responded 'Yes' to the survey question, though there was considerable variation by electoral division, as shown in Figure 2. The percentage 'Yes' response ranged from a low of $26.1 \%$ in the western Sydney electorate of Blaxland to a high of $83.7 \%$ in the inner city electorates of Sydney and Melbourne. Although only 17 of the 150 electoral divisions had 'Yes' responses under 50\%, electorates closer to State and Territory capital city centres were more strongly supportive of changing the law compared to rural and remote electorates. Examining the majority 'No' responding electoral divisions (Figure 3), there was an obvious clustering in western Sydney and rural Queensland (west and north-west). The two remaining 'No' electorates were in Melbourne, but geographically separated.

Figures 2 about here

Figure 3 about here

\subsection{Bivariate relationships}

Figure 4 shows the relationship between the percentage 'Yes' vote and each of the 11 independent variables. The strongest positive linear relationships were evident for the 
percentage of people with no religion and the percentage with post-school education. Positive relationships were also observed for the log of percentage of adults in same-sex relationships, the proportion of females, AMLPS participation and the participation of those aged 18-34, and the percentage of those on high incomes. Weaker positive associations were evident for the log of percentage born in Oceania, Europe and the Americas, and the log of population density. No clear relationship was observed with the percentage of people voting for the Coalition in the 2016 federal election and the percentage of eligible voters aged 18-34.

Figure 4 about here

\subsection{Linear regression}

An ordinary least squares linear regression model was initially fitted to the data, with all independent variables included (Model 1). The results are provided in Table 2. It shows that most relationships between the 'Yes' vote and the independent variables are in the expected direction, except for a slight negative relationship with the overall participation rate. Model 1 explains $92.3 \%$ of the geographic variation in the 'Yes' vote but includes a number of nonsignificant independent variables at $\mathrm{p}<0.05$, namely: log of percentage adults in same-sex relationships, percentage females, percentage younger people, and participation rate.

Table 2 about here

After applying the backward step regression process, the optimised regression model - Model 2 - explains $91.8 \%$ of the variation in the 'Yes' outcome with a small number of population characteristics of each electorate: no religion, post-school qualifications, being born in Oceania, Europe and the Americas, Liberal/National voting in the last federal election, and 
the population density of the electorate. All the predictors were highly significant at $\mathrm{p}<0.001$ and the variance inflation factor showed no significant collinearity between them.

As expected, all independent variables had a strong and positive correlation with the 'Yes' outcome except for the percentage of Liberal/National voting which had an expected negative relationship (Table 2). Model 2 predicts that a 1 percentage point increase in the percentage of Coalition voting decreases the percentage of 'Yes' responses by 0.15 percentage points, while a 1 percentage point increase in the percentage of the population with no religion increases the percentage of 'Yes' responses by 0.5 percentage points. A 1 percentage point increase in the percentage of the population with any post school education increases the percentage of 'Yes' responses by 0.6 percentage points. Being born in countries in Oceania, Europe and the Americas had a slightly lower impact on the 'Yes' outcome in an electorate. The model predicts that a 1 percentage point increase in the percentage of people born in these countries increases the mean percentage of 'Yes' responses by 0.42 percentage points' . A 1 percentage point increase in population density only increases the percentage of 'Yes' responses by 0.006 percentage points.

These results show that the simple linear regression model appears to perform well. However, it is a global model which assumes that the relationship between the variables and the percentage 'Yes' outcome is the same across all electorates in the country. Mapping of the dichotomous overall 'Yes' and 'No' outcome by electoral division identified a strong clustering of 'No' electorates in western Sydney and the rural west and north west of Queensland. Considering there were only 17 majority 'No' electorates in Australia, these

\footnotetext{
${ }^{1}$ When interpreting the logged coefficient we used the Taylor expansion of the function $f(x)=\log (1+x)$ around $x_{0}=0$, to give us $\log (1+x)=x+O^{\prime}\left(x^{2}\right)$. Therefore in our example we can say that for a $1 \%$ increase in the percentage of people born in Oceania, Europe and the Americas, the difference in the expected mean percentage 'Yes' responses will be $\beta^{3} \times \log (1.01)=42.52 \times 0.00995=0.423$.
} 
clusters accounted for 15 of those. We therefore applied geographic weighting to determine whether it would improve on the global model and offer new insights.

\subsection{Geographically weighted regression}

Results from the geographically weighted regression - Model 3 - are presented in Table 3. The geographical variability test in GWR4 indicated that population density was the only variable that did not vary significantly in its relationship with the percentage 'Yes' outcome. All other independent variables gave improved results when they were allowed to vary across electoral divisions, so we selected this form of model (see the supplementary material for results of the geographical variability test). Table 3 reports the coefficient, standard error and t-statistic for population density (as the global variable) and the mean, median, lower and upper quartiles for the coefficients of the remaining variables that were allowed to vary spatially.

Table 3 about here

Model 3 shows a slight improvement over Model 2, with the overall adjusted $\mathrm{R}^{2}$ increasing from 0.918 to 0.933 and the AIC declining from 754 to 728 . Both measures indicate that GWR provides a better fit with the data and increased accuracy. However, whether this improvement assists in understanding whether sympathetic attitudes to and behaviours towards non-heterosexual populations vary geographically is debatable. The direction of the relationship between the locally varying independent variables is entirely consistent with the global model (Model 2), and the observed difference in the range of coefficient values is fairly small. 
In Model 3, the largest difference between the predicted and actual outcome was 10.7 percentage points, which was for the electorate of Eden-Monaro on the southern coast of New South Wales. The smallest difference was 0.03 percentage points for Petrie in the Queensland capital city of Brisbane, while the median absolute residual was 1.5 percentage points. A scatterplot of residuals (not shown) confirms no obvious pattern of the predicted outcomes being higher or lower than the 'Yes' outcome, and a visual comparison of the residuals for both Models 2 and 3 suggests a slightly tighter pattern for Model 3 .

Model 3 predicted the wrong outcome in terms of the dichotomous 'Yes' versus 'No' result in only 5 electorates. These are listed in Table 4 . These were all majority 'No' electorates, and comprised two of the electorates in regional Queensland and three in western Sydney.

The residuals ranged between 2.5 and 7.3 percentage points. In comparison, Model 2 predicted an incorrect dichotomous outcome in 8 electorates where the residuals ranged between 1.6 and 7.8. The same five electorates as well as another in western Sydney were predicted incorrectly as majority 'Yes' electorates. Model 2 also predicted two electorates as majority 'No' voting which actually voted 'Yes' - one in rural New South Wales and another in Melbourne.

Table 4 about here

\section{DISCUSSION AND CONCLUSION}

This study has shown the highest percentage of 'Yes' votes in the Australian Marriage Law Postal Survey were recorded in the larger cities of Australia, especially in the inner suburbs. At the same time many rural electorates - perhaps surprisingly given their conservative reputations - returned majority 'Yes' votes, albeit with smaller margins. Our modelling 
revealed that the percentage of 'Yes' votes in each electoral division was positively associated with the percentage of the Australian citizen population aged 18 years and above with: no religion; post-school educational qualifications; a birthplace in Oceania, Europe or the Americas; and population density. It was negatively associated with the percentage of people who voted for the Liberal/National Coalition in the 2016 federal election. The linear regression model (Model 2) and the geographically-weighted model (Model 3) respectively explained $92 \%$ and $93 \%$ of the geographic variability in the 'Yes' vote. Even though this is an ecological rather than an individual-level analysis, these are better fits than we had expected. Part of the explanation may lie in the relatively coarse geography of just 150 electoral divisions; part of it may also be due to strong associations of certain population characteristics with attitudes and therefore with the way people voted in the AMLPS.

Similarly high $\mathrm{R}^{2}$ values have been obtained in other ecological studies (e.g. Matti and Zhou, 2017).

Although the literature suggests other population characteristics are associated with attitudes to same-sex relationships, six out of the 11 electorate-level independent variables were not significantly influential and were excluded from the final models (Models 2 and 3). The participation of younger people approached significance at $\mathrm{p}<0.1$ and the percentage of people on personal incomes of $\$ 2000$ or more per week was significant at $\mathrm{p}<0.05$, but excluded when the model was optimised. The percentage of females did not vary much across electoral divisions having a standard deviation of only 1.0 percentage point, which may explain its modest explanatory power. The range of other variables, including the percentages of younger people, those with high personal income, and participation rates, was also quite limited. The lack of significance for survey participation is at odds with the results of McAllister \& Snagovsky (2018). The percentage of adults in cohabiting same-sex 
relationships in any electorate was very small - ranging from just $0.07 \%$ in the electorate of Fowler (a 'No' voting electorate in western Sydney) to $2.7 \%$ in the electorate of Sydney (inner Sydney) - and again may not have been varied enough to pick up differences in voting patterns.

Both Models 2 and 3 do a respectable job in predicting the percentage 'Yes' vote by electoral division throughout the country, with the median absolute residuals being just 1.6 and 1.5 percentage points respectively. Even where the prediction of a majority 'Yes' vote in an electorate was incorrect, it was mostly just a few percentage points out (Table 4). In Model 3 the GWR local $\mathrm{R}^{2}$ ranged from a minimum of 0.90 (Lingiari) to a maximum of 0.95 (Indi). Part of the explanation of these good fits may be due to the universally strong influence of religion and education in shaping attitudes and voting in the AMLPS.

In terms of the limitations of our study, one key aspect is that it does not use individual-level data because such data were not collected in the AMLPS. Our models are not designed to predict individual-level behaviour, and should not be used to infer it. Nonetheless, our results are largely consistent with the individual-level analysis of HILDA Survey data by Perales \& Campbell (2018). Other limitations include the use of independent variables not perfectly aligned with the timing of the AMLPS vote, and known deficiencies in census data such as net undercount and some imputation.

It is also the case that our models are likely to have declining validity over time because they reflect the attitudes of Australian citizens at the time of the AMLPS. It is known that attitudes to same-sex couples and non-heterosexual individuals have been shifting rapidly in recent years (Baunach, 2012; Wilkins, 2017). Importantly, some research indicates that legislative 
reform can promote attitudinal change (Flores \& Barclay, 2016). If the same question about same-sex marriage were to be asked in a few years' time we would expect changes to the coefficients of the models reflecting changed attitudes.

These changed attitudes to same-sex marriage and same-sex relationships in Australia are likely, but not guaranteed, to become more favourable in the future. The proportion of Australians with post-school qualifications is increasing (ABS, 2017d) while the proportion reporting no religion is also rising (ABS, 2017e). Australia's biggest cities are experiencing fast growth and population density is rising, although density was shown to have only a modest influence in our models. On the other hand, Australia's immigrant intake is becoming increasingly diverse, and this may exert influence in the opposite direction. And geography matters. At the regional and local scale the percentage of the population taking a positive view of same-sex relationships is likely to vary considerably in the future as it did at the time of the AMLPS, and will be associated to a considerable extent with the geography of population composition.

\section{References}

ABS (2017a). Report on the conduct of the Australian Marriage Law Postal Survey 2017.

Catalogue Number 1800.0. Canberra: ABS.

http://www.abs.gov.au/AUSSTATS/abs@.nsf/DetailsPage/1800.02017?OpenDocumen $\mathrm{t}$ (accessed 6 August 2018).

ABS (2017b). Australian Marriage Law Postal Survey. Catalogue Number 1800.0. Canberra: ABS.http://stat.data.abs.gov.au/Index.aspx?DataSetCode=AMLPS_RESP_2017 (accessed 6 August 2018). 
ABS (2017c). Census of Population and Housing, 2016, TableBuilder. Findings based on use of TableBuilder data. Canberra: ABS. https://auth.censusdata.abs.gov.au/webapi/jsf/tableView/tableView.xhtml\# (accessed 6 August 2018).

ABS (2017d). Census of Population and Housing: Reflecting Australia - Stories from the Census, 2016: Educational qualifications in Australia. http://www.abs.gov.au/ausstats/abs@.nsf/Lookup/by\%20Subject/2071.0 2016 Main\% 20Features Educational\%20Qualifications\%20Data\%20Summary\%20 65 (accessed 29 Oct 2018).

ABS (2017e). Census of Population and Housing: Reflecting Australia - Stories from the Census, 2016: Religion in Australia. http://www.abs.gov.au/ausstats/abs@.nsf/Lookup/by\%20Subject/2071.0 2016 Main\% 20Features Religion\%20Article $\sim 80$ (accessed 29 Oct 2018).

ABS (2018). Regional Population Growth, Australia, 2016-17. Catalogue Number 3218.0. Canberra: ABS. http://www.abs.gov.au/AUSSTATS/abs@.nsf/DetailsPage/3218.0201617?OpenDocument (accessed 8 August 2018).

AEC (2017). 2016 Federal Election House of Representatives Two Party Preferred by

Division https://results.aec.gov.au/20499/Website/Downloads/HouseTppByDivisionDownload20499.txt (accessed 8 August 2018).

Anderson, J., Georgantis, C., \& Kapelles, T. (2017). Predicting support for marriage equality in Australia. Australian Journal of Psychology, 69(4), 256-262. doi:10.1111/ajpy.12164 
Armenia, A., \& Troia, B. (2017). Evolving Opinions: Evidence on Marriage Equality

Attitudes from Panel Data. Social Science Quarterly, 98(1), 185-195. doi:10.1111/ssqu.12312

Baunach, D. M. (2012). Changing same-sex marriage attitudes in America from 1988 through 2010. Public Opinion Quarterly, 76(2), 364-378. doi:10.1093/poq/nfs022

Chamie, J., \& Mirkin, B. (2011). Same-sex marriage: a new social phenomenon. Population and Development Review, 37(3), 529-551. Retrieved from http://www.jstor.org/stable/23036054

Flores, A. R., \& Barclay, S. (2016). Backlash, consensus, legitimacy, or polarization: the effect of same-sex marriage policy on mass attitudes. Political Research Quarterly, 69(1), 43-56. doi:10.1177/1065912915621175

Fotheringham, A. S., Brunsdon, C., \& Charlton, M. (2000). Quantitative Geography: Perspectives on Spatial Data Analysis. London: SAGE.

Fotheringham, A. S., Brunsdon, C., \& Charlton, M. (2002). Geographically Weighted Regression: The Analysis of Spatially Varying Relationships. Chichester: Wiley. Kassambara, A. (2018). Stepwise Regression Essentials in R. Statistical tools for high throughput data analysis. http://www.sthda.com/english/articles/37-model-selectionessentials-in-r/154-stepwise-regression-essentials-in-r/ (accessed 13 August 2018).

Matti, J., \& Zhou, Y. (2017). The political economy of Brexit: explaining the vote. Applied Economics Letters, 24(16), 1131-1134. doi:10.1080/13504851.2016.1259738

McAllister, I., \& Snagovsky, F. (2018). Explaining voting in the 2017 Australian same-sex marriage plebiscite. Australian Journal of Political Science, 53(4), 409-427. doi:10.1080/10361146.2018.1504877 
McKeown, D. (2017). Chronology of same-sex marriage bills introduced into the federal parliament: a quick guide. Parliamentary Library Research Paper Series, 2017-18. Retrieved from http://apo.org.au/node/121006

Nakaya T., Charlton, M., Brunsdon, C., Lewis, P., Yao, J., \& Fotherington, A. S. (2016). GWR4 Windows Application for Geographically Weighted Regression Modelling. Retrieved from http://gwr.maynoothuniversity.ie/gwr4-software/

Pennay, D., Bongiorno, F., \& Myers, P. (2018). The Life in Australia Historic Events Survey. Canberra: Social Research Centre, Australian National University. Retrieved from http://cdn.srcentre.com.au/le2017/documents/SRC_HES_Topline_Report.pdf

Perales, F., \& Campbell, A. (2018). Who supports equal rights for same-sex couples? Family Matters, 100, 28-41. Retrieved from https://aifs.gov.au/publications/familymatters/issue-100/who-supports-equal-rights-same-sex-couples

Perales, F., Bouma, G., \& Campbell, A. (2018). Religion, support of equal rights for samesex couples and the Australian National Vote on Marriage Equality. Sociologyof Religion. doi:10.1093/socrel/sry018

Perales, F., \& Todd, A. (2018). Structural stigma and the health and wellbeing of Australian LGB populations: Exploiting geographic variation in the results of the 2017 same-sex marriage plebiscite. Social Science \& Medicine, 208, 190-199.

doi:10.1016/j.socscimed.2018.05.015

Oppenheimer, D. B., Oliveira, A., \& Blumenthal, A. (2014). Religiosity and Same-Sex Marriage in the United States and Europe. Berkeley Journal of International Law, 32(1), 195-238. doi:10.15779/Z38S93

R Development Core Team, (2018). R: A Language and Environment for Statistical Computing. The R Foundation for Statistical Computing, Vienna, Austria. Available online at http://www.R-project.org/ 
Sloane, J., \& Robillard, L. (2018). Factors Affecting Heterosexual Attitudes to Same-Sex Marriage in Australia. Sexuality Research and Social Policy, 15(3), 290-301. doi:10.1007/s13178-017-0276-y

Smith, S. J., Axelton, A. M., \& Saucier D. A. (2009). The effects of contact on sexual prejudice: a meta-analysis. Sex Roles, 61(3-4), 178-191. doi:10.1007/s11199-009-9627-3

Smith, J. F. N. (2016). Same-Sex Marriage Attitudes During the Transition toEarly Adulthood: A Panel Study of Young Australians, 2008 to 2013. Journal of Family Issues, 37(15), 2163-2188. doi:10.1177/0192513X14560644

Webb, S. N., \& Chonody, J. (2014). Heterosexual Attitudes Toward Same-Sex Marriage: The Influence of Attitudes Toward Same-Sex Parenting. Journal of GLBT Family Studies, 10(4), 404-421. doi:10.1080/1550428X.2013.832644

Wilkins, R. (2017). Attitudes to marriage, parenting and work. In The Annual Statistical Report of the HILDA Survey (12): Selected Findings from Waves 1 to 15. Melbourne Institute Applied Economic \& Social Research, 98-109.

Wilson, T., \& Shalley, F. (2018). Estimates of Australia's non-heterosexual population. Australian Population Studies, 2(1), 26-38. Retrieved from http://www.australianpopulationstudies.org/index.php/aps/article/view/23 
Table 1: Descriptive statistics of the variables by federal electoral division

\begin{tabular}{|c|c|c|c|c|c|}
\hline Variable & Mean & Median & $\begin{array}{r}\text { Standard } \\
\text { deviation }\end{array}$ & Minimum & Maximum \\
\hline $\begin{array}{l}\text { Dependent variable } \\
\text { \% 'Yes' votes } \\
\text { (YES) }\end{array}$ & 61.2 & 61.8 & 10.2 & 26.1 & 83.7 \\
\hline \multicolumn{6}{|l|}{ Independent variables } \\
\hline $\begin{array}{l}\% \text { overall survey participation } \\
\text { (PARTIC) }\end{array}$ & 79.4 & 80.0 & 4.3 & 50.1 & 86.0 \\
\hline $\begin{array}{l}\% \text { participation of younger } \\
\text { people }(18-34) \\
\text { (YOUNG_PARTIC) }\end{array}$ & 72.6 & 72.5 & 6.2 & 43.2 & 84.3 \\
\hline$\%$ females & 51.5 & 51.5 & 1.0 & 46.1 & 53.2 \\
\hline $\begin{array}{l}(\text { PER_FEM }) \\
\% \text { younger people }(18-34) \\
\text { (PER_YOUNG) }\end{array}$ & 27.5 & 27.2 & 4.6 & 17.1 & 44.6 \\
\hline $\begin{array}{l}\% \text { with post school } \\
\text { qualifications } \\
\text { (POSTSCHED) }\end{array}$ & 53.7 & 52.7 & 7.7 & 36.8 & 72.7 \\
\hline $\begin{array}{l}\text { \% with high personal income } \\
\text { (\$2000+ per week) } \\
\text { (PER HIGHINC) }\end{array}$ & 9.8 & 7.9 & 5.9 & 3.3 & 30.9 \\
\hline $\begin{array}{l}\% \text { with birthplace in Oceania, } \\
\text { Europe \& the Americas } \\
\text { (logged) (LN_BIRTH) }\end{array}$ & 4.5 & 4.5 & 0.1 & 4.0 & 4.6 \\
\hline $\begin{array}{l}\% \text { with no religion } \\
\text { (NO_REL) }\end{array}$ & 29.7 & 30.0 & 7.3 & 11.2 & 50.5 \\
\hline $\begin{array}{l}\% \text { people in same-sex } \\
\text { relationships (logged) } \\
(\mathrm{LN} \text { _SAME) }\end{array}$ & -0.9 & -1.0 & 0.6 & -2.1 & 1.6 \\
\hline $\begin{array}{l}\% \text { voting Liberal/National } \\
\text { Party } \\
(\text { PER_LNP) }\end{array}$ & 50.3 & 51.1 & 11.3 & 27.6 & 74.9 \\
\hline $\begin{array}{l}\text { Population density (logged) } \\
\text { (LN_DENSITY) }\end{array}$ & 5.2 & 6.1 & 2.8 & -2.4 & 8.5 \\
\hline
\end{tabular}


Table 2: Linear regression results

\begin{tabular}{|c|c|c|c|c|c|c|}
\hline & \multicolumn{3}{|c|}{ Model 1} & \multicolumn{3}{|c|}{ Model 2} \\
\hline & Coeff. & $\begin{array}{l}\text { Standa } \\
\text { rd } \\
\text { error }\end{array}$ & $p$ & Coeff. & $\begin{array}{c}\text { Standar } \\
\text { d } \\
\text { error }\end{array}$ & $p$ \\
\hline $\begin{array}{l}\text { \% No religion } \\
\text { (NO_REL) }\end{array}$ & 0.50 & 0.05 & $<0.001$ & 0.50 & 0.05 & $<0.001$ \\
\hline $\begin{array}{l}\% \text { Post-school } \\
\text { education } \\
\text { (POSTSCHED) }\end{array}$ & 0.38 & 0.10 & $<0.001$ & 0.61 & 0.05 & $<0.001$ \\
\hline $\begin{array}{l}\text { \% Birthplace Oceania, } \\
\text { Europe \& Americas } \\
\text { (logged) (LN_BIRTH) }\end{array}$ & 43.70 & 3.48 & $<0.001$ & 42.52 & 2.78 & $<0.001$ \\
\hline $\begin{array}{l}\% \text { people in same-sex } \\
\text { relationships } \\
\text { (logged) (LN_SAME) }\end{array}$ & 0.62 & 0.75 & 0.408 & & & \\
\hline $\begin{array}{l}\text { Population density of } \\
\text { electorate } \\
\text { (logged) }\end{array}$ & 0.53 & 0.19 & 0.006 & 0.60 & 0.15 & $<0.001$ \\
\hline (LN_DENSITY) & & & & & & \\
\hline $\begin{array}{l}\% \text { Liberal/National } \\
\text { voting } \\
(\text { PER_LNP) }\end{array}$ & -0.12 & 0.03 & $<0.001$ & -0.15 & 0.03 & $<0.001$ \\
\hline $\begin{array}{l}\% \text { Females } \\
(\text { PER_FEM) }\end{array}$ & 0.46 & 0.35 & 0.197 & & & \\
\hline $\begin{array}{l}\text { \% Younger people } \\
\text { (PER_YOUNG) }\end{array}$ & 0.10 & 0.09 & 0.249 & & & \\
\hline $\begin{array}{l}\% \text { High personal } \\
\text { income } \\
\text { (PER_HIGHINC) }\end{array}$ & 0.19 & 0.09 & 0.042 & & & \\
\hline $\begin{array}{l}\% \text { Participation } \\
\text { (PARTIC) }\end{array}$ & -0.17 & 0.16 & 0.292 & & & \\
\hline$\%$ Participation & 0.19 & 0.11 & 0.093 & & & \\
\hline $\begin{array}{l}\text { younger people } \\
\text { (YOUNG_PARTIC) }\end{array}$ & & & & & & \\
\hline $\mathrm{n}$ & 150 & & & & & \\
\hline Adjusted $\mathrm{R}^{2}$ & 0.923 & & & 0.918 & & \\
\hline $\mathrm{F}(11,138)$ & $162.2(p$ & $<0.001)$ & $\mathrm{F}(5,144)$ & $336.1(p$ & $<0.001)$ & \\
\hline $\mathrm{AIC}$ & 751.6 & & & 753.9 & & \\
\hline
\end{tabular}


Table 3: Geographically Weighted Regression results

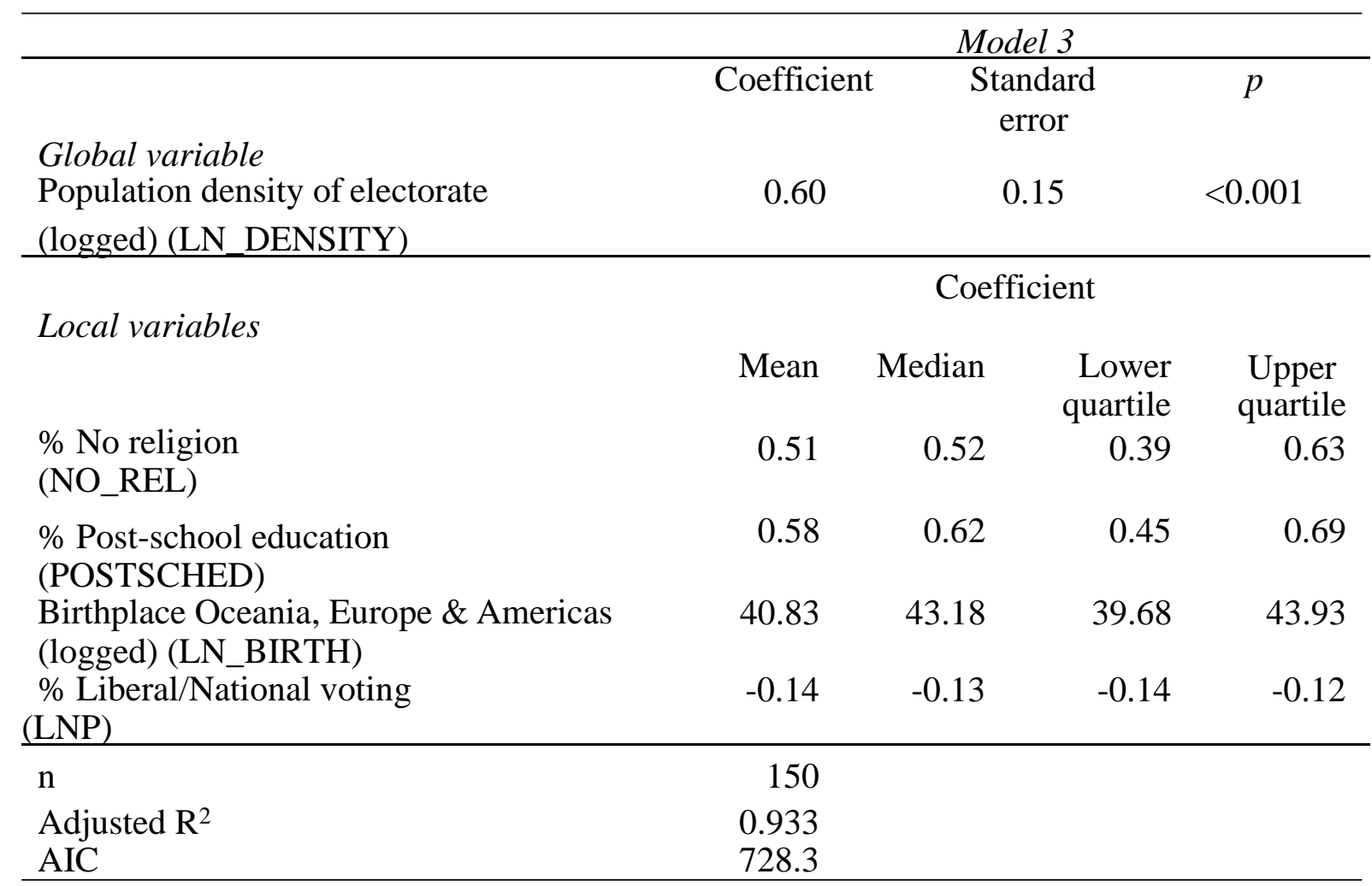


Table 4: Predicted and actual 'Yes' vote percentages for electorates with incorrectly

$\frac{\text { predicted majority votes, Models } 2 \text { and } 3}{\text { Model } 2 \quad \text { Model } 3(\text { GWR })}$

Electoral division Predicte Actual Predicted Actual

$\begin{array}{lllll}\text { Banks (Sydney) } & 51.2 & 44.9 & 50.5 & 44.9\end{array}$

Barton (Sydney)

$\begin{array}{llll}51.4 & 43.6 & 50.9 & 43.6\end{array}$

Bennelong (Sydney)

$\begin{array}{llll}53.8 & 49.8 & 52.3 & 49.8\end{array}$

Groom (Rural Queensland)

$\begin{array}{llll}54.9 & 49.2 & 54.0 & 49.2\end{array}$

Kennedy (Remote Queensland)

$52.0 \quad 46.7$

Mitchell (Sydney)

$52.8 \quad 49.1$

Parkes (Rural New South $\quad 48.2 \quad 52.7$

Wales)

Holt (Melbourne) $49.1 \quad 50.7$

Source: ABS (2017b) for actual 'Yes' response percentages 


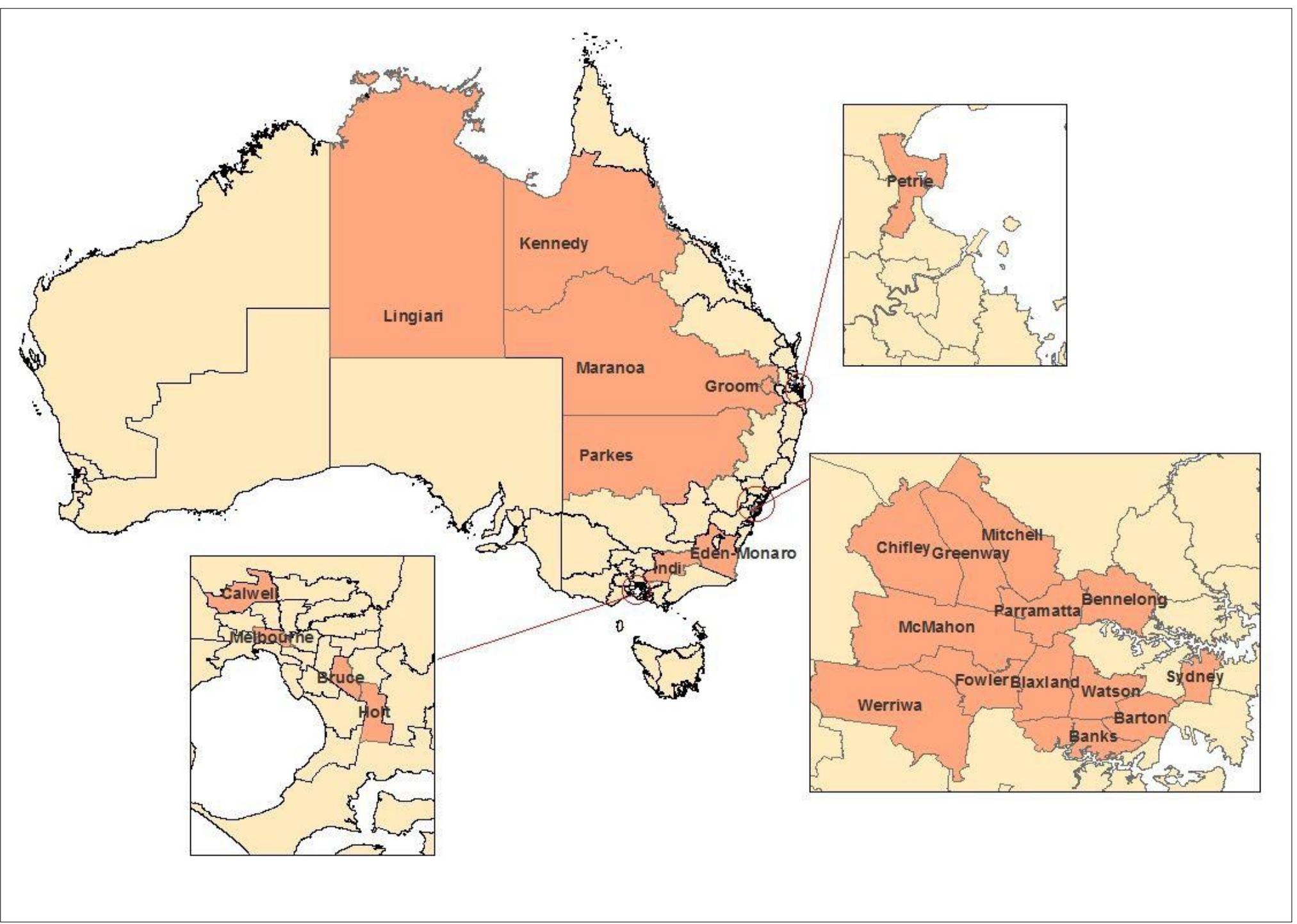

Figure 1: Australian federal electoral divisions, 2017

Source: ABS (2017c) 


${ }^{46}$

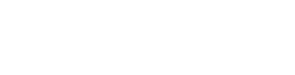

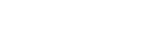

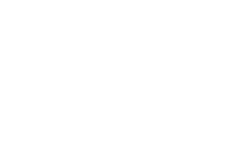

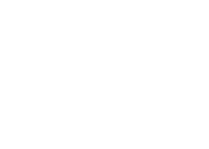

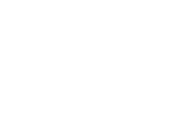

-

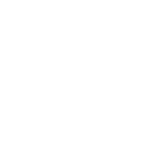

(2)

.

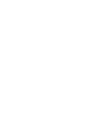

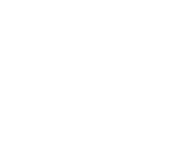

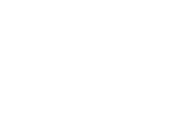

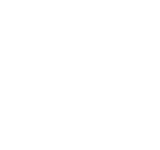

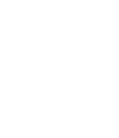

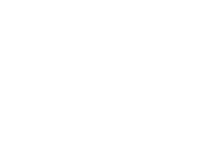

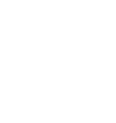

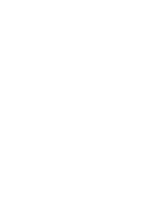

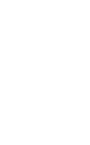

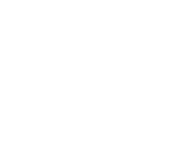

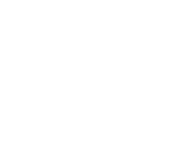

. 



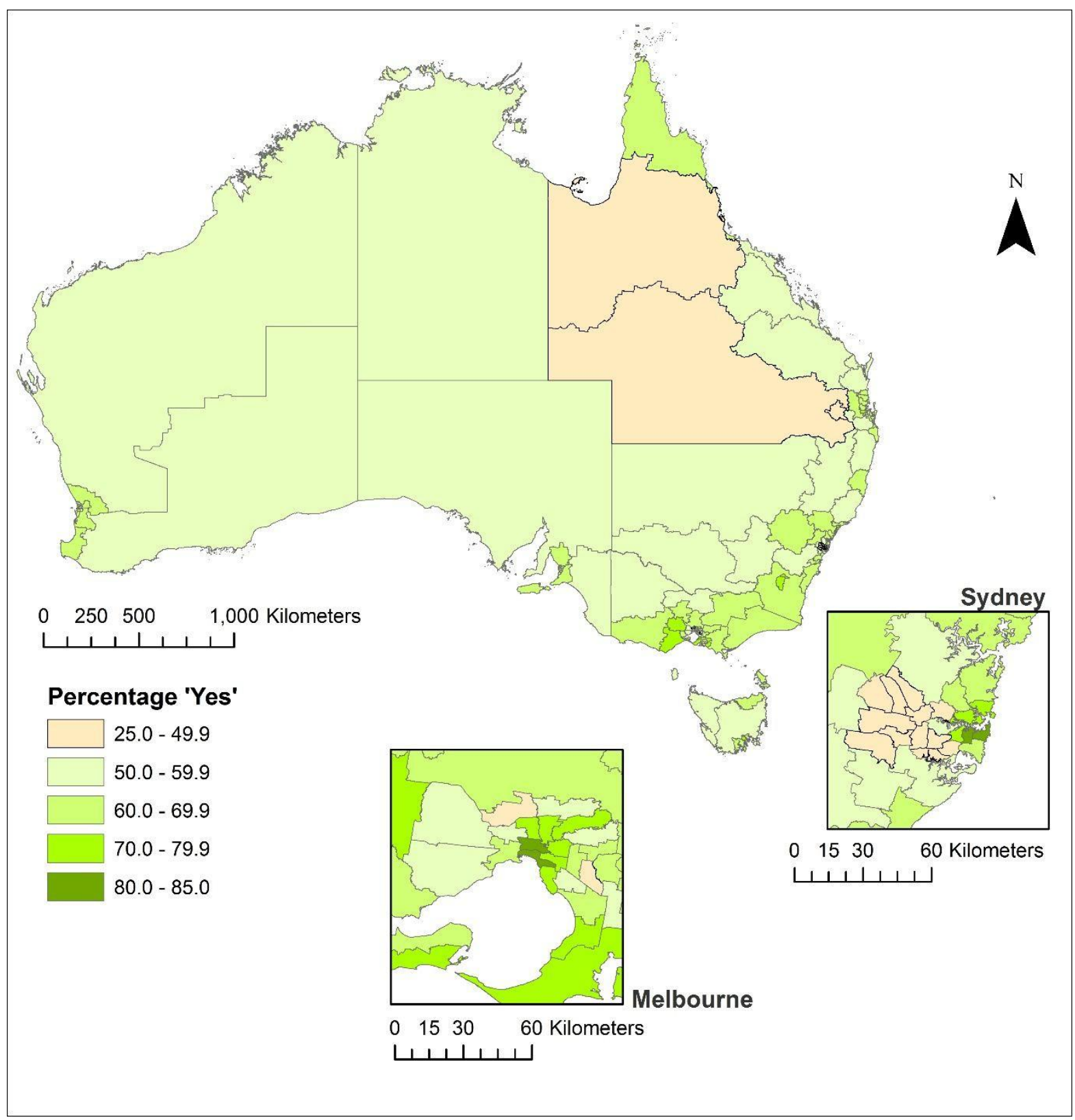

Figure 2: Percentage 'Yes' votes in the Australian Marriage Law Postal Survey by federal electoral division Source: ABS (2017b) 


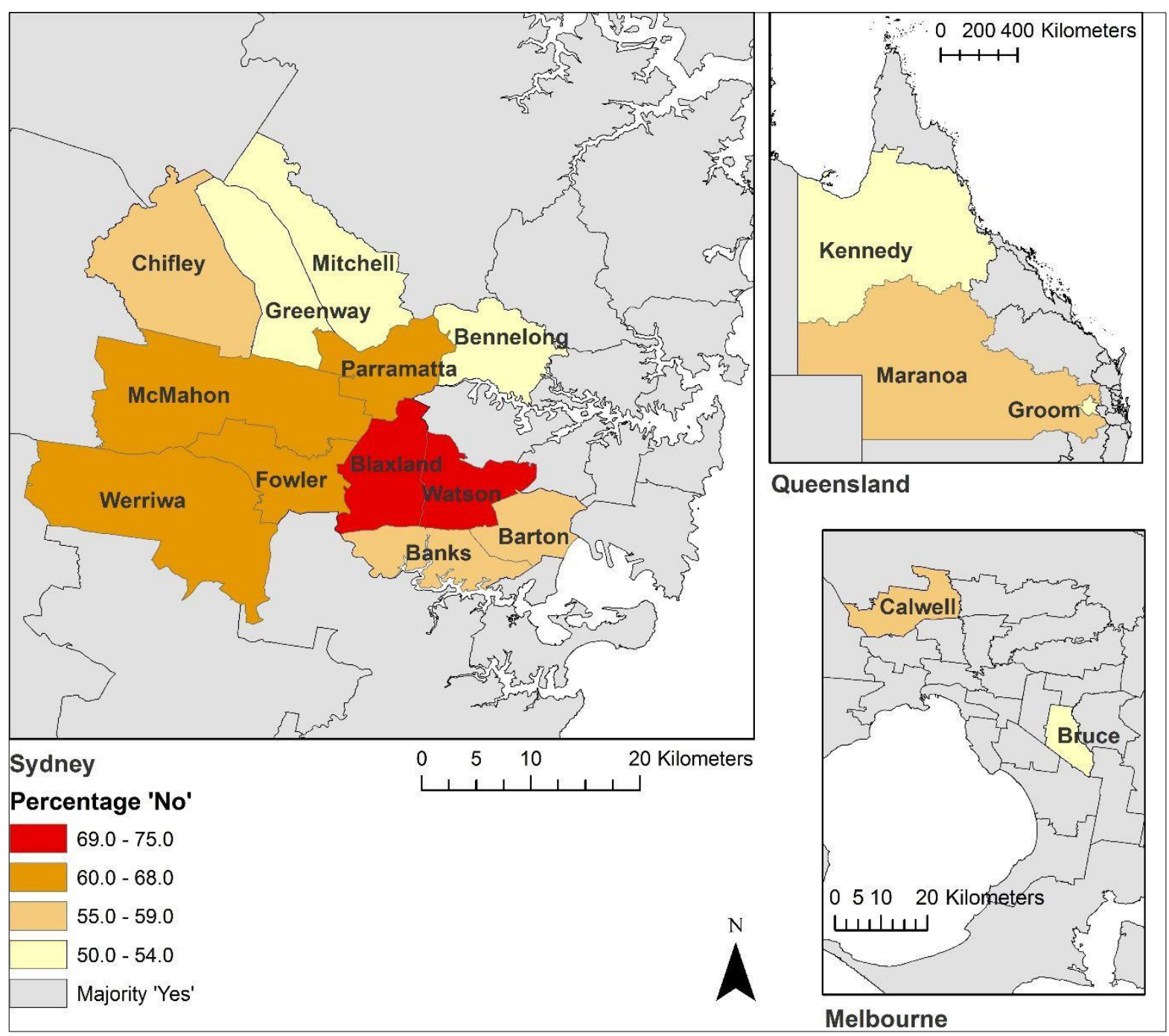

Figure 3: Percentage 'No' votes in federal electoral divisions returning majority 'No' votes in the Australian Marriage Law Postal Survey Source: ABS (2017b) 


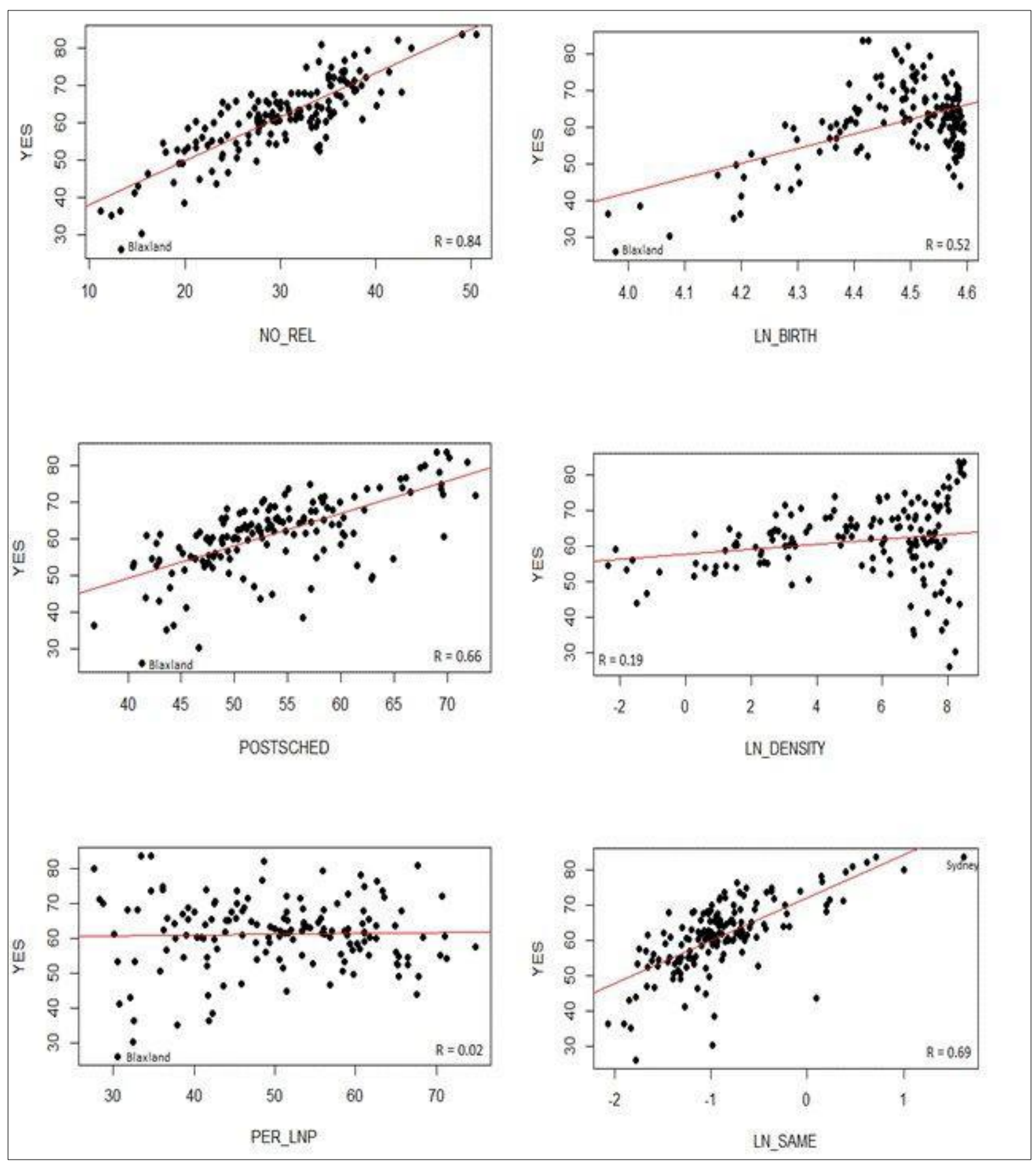

Figure 4: Scatterplots of the relationship between percentage 'Yes' vote and independent variables 

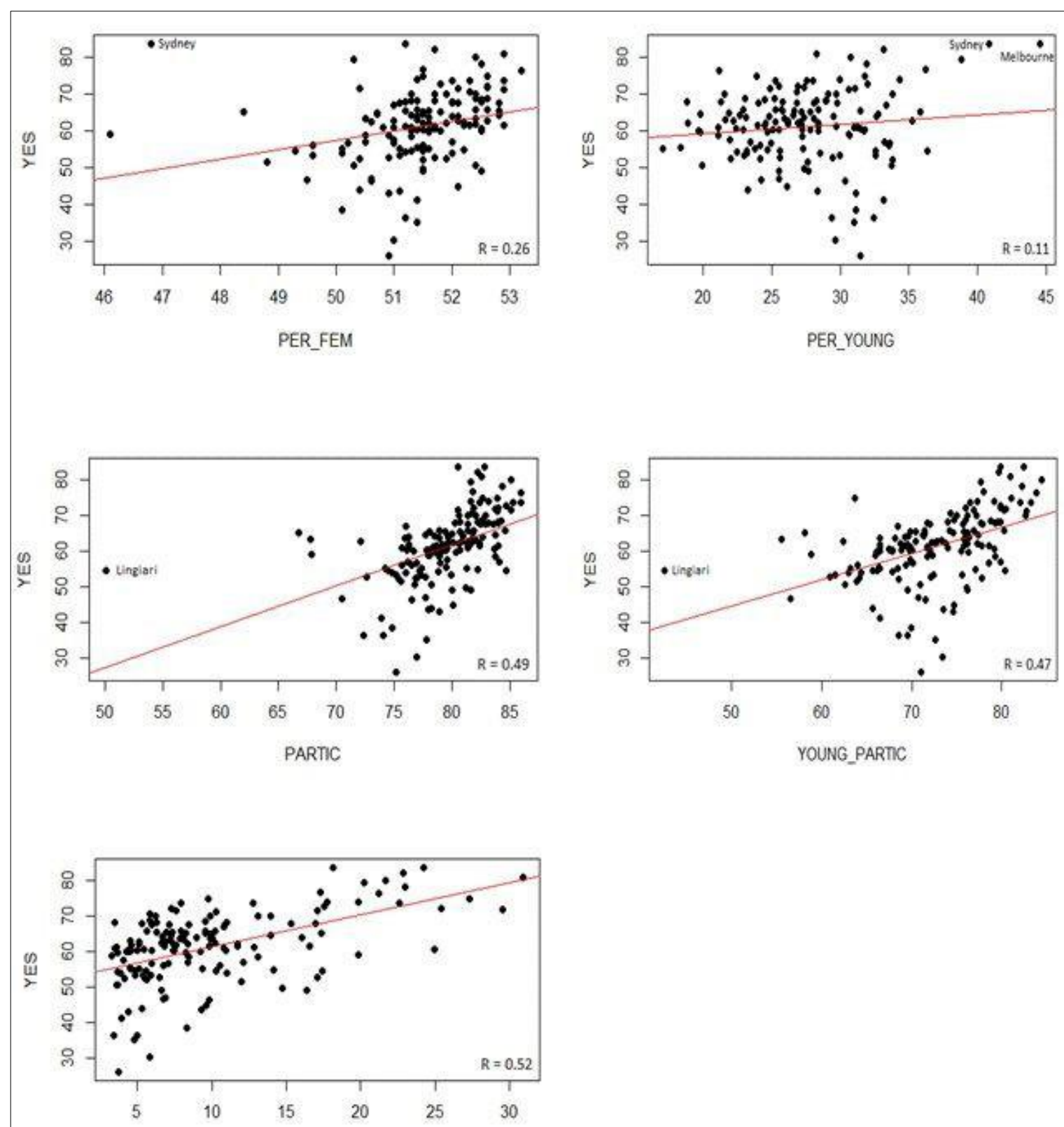

PER HIGHINC

Figure 4 continued 